\title{
VILMOSKÖRTE PÁRLATOK GÁZKROMATOGRÁFIÁS ÉS ÉRZÉKSZERVI PROFILANALITIKUS EREDMÉNYEINEK ELEMZÉSE EGY- ÉS TÖBBVÁLTOZÓS STATISZTIKAI MÓDSZEREKKEL
}

\author{
Sipos László - Kovács Sándor - Nagygyörgy László - Lázár János - Gere Attila - \\ Kókai Zoltán
}

\begin{abstract}
Absztrakt: A nemzetközi kutatási eredmények azt mutatják, hogy a müszeres analitikai eredmények és az emberi érzékelés paraméterei között nagyfokú korreláció adódik a termékek különbözö összetevöire vetítve. Munkánkban célul tüztük ki 6 magánfözött és 4 kereskedelmi forgalomban kapható vilmoskörte párlat gázkromatográfiás (GC-MS) és érzékszervi profilanalitikus vizsgálatát. A gázkromatográfiás vizsgálatokat a Wessling Hungary $\mathrm{Kft}$. végezte, míg az érzékszervi profilanalitikus vizsgálatokat (ISO 13299:2016) a Szent István Egyetem Érzékszervi Minősítő Laboratóriumában (ISO 8589:2007) szakértöi bírálócsoport segítségével (ISO 8586:2012) végeztük. Az egyváltozós elemzésekkel illó komponensenként és érzékszervi tulajdonságonként értékeltük az egyes párlatokat, az érzékszervi bírálói teljesítmény megfelelőségének szoftveres értékelése után (PanelCheck, ISO 11132:2012). Munkánkban sokdimenziós térredukciós módszerek matematikai módszereket alkalmazunk (principal component analysis, PCA; multiple factor analysis, MFA). Eredményeinkben bemutatjuk az érzékszervi és analitikai dimenziók közötti összefüggéseket, melyek során többek között alátámasztottuk, hogy a vilmoskörte vezéraromák (metil-2-transz-4-cisz-dekadienoát, etil-2transz-4-ciszdekadienoát) szoros kapcsolatban vannak a körte iz érzékszervi dimenziójával.
\end{abstract}

\begin{abstract}
International research results show, there is a high correlation between instrumental analytical results and human perception parameters based on the different components of the products. Our goal is to examine six 'home' distilled and four commercially available Williams pear distillates with gas chromatography (GC-MS) method and perform a sensory profile analysis test. Gas chromatography tests were performed by Wessling Hungary Ltd. (ISO 13299:2016) while the sensory profile analysis sessions (ISO 13299:2016) were performed in the sensory laboratory of Szent István University (ISO 8586:2012) involving an expert sensory panel. One by one we evaluated the individual distillates per volatile component and sensory properties with one-variable analyses, after evaluating the sensory evaluation performance of the software (PanelCheck, ISO 11132:2012). In our work, we use spatial reduction mathematical methods (principle component analysis, PCA; multiple factor analysis, MFA). In our results, we demonstrate the relations between the sensory and the analytical dimensions; we confirmed the fact, that the main aromas of Williams pear (methyl-2-trans4-cis-decadieoate, ethyl-2-trans-4-cisdekadieoate) are closely related to the sensory dimension of pear flavour.
\end{abstract}

Kulcsszavak: pálinka, aromakomponensek, fökomponens elemzés (PCA), többszörös faktorelemzés (MFA), gázkromatográfia, érzékszervi bírálócsoport

Keywords: pálinka, aroma components, principal component analysis (PCA), multiple factor analysis (MFA), gas chromatography, sensory panel

\section{Bevezetés}

A pálinkáról, a törkölypálinkáról és a Pálinka Nemzeti Tanácsról szóló 2008. évi LXXIII. törvény (röviden Pálinkatörvény) jogilag határozza meg a pálinka szó jelentését. A Pálinkatörvény 2 . § szerint a pálinkának nevezhetjük azt a gyümölcspárlatot, ami eleget tesz a következőknek: 
- Magyarországon termett gyümölcsből, gyümölcsvelővel készült, és amelynek cefrézését, párlását, érlelését és palackozását is Magyarországon végezték.

- $\quad$ A pálinkát nem lehet ízesíteni, színezni, édesíteni még a termék végső ízének lekerekítése érdekében sem (kivéve enzimek, savak, élesztők, derítőszerek, nehézfémek eltávolítására alkalmas segédanyagok, habzásgátló, tápsó).

- Minimum 37,5\% V/V, maximum 86\% V/V alkoholszázalékos lehet.

- Pálinka nevet kizárólag Magyarország használhatja, kivéve 4 osztrák tartományt, ahol készülhet „barackpálinka” megnevezéssel gyümölcspárlat.

A Pálinkatörvénynek nagy szerepe van a minöségi pálinkák elterjedésében, ugyanakkor a technológiai hibamentesség csak a pálinka készítés jó gyakorlatainak betartása mellett érhető el (gyümölcs minősége, feldolgozása, helyes cefrézés, megfelelő lepárlási és elválasztási paraméterek stb.). A párlat ezzel szemben „csak” valamilyen cukrot tartalmazó alapanyagból erjesztéssel és lepárlással készülő ital. A párlat továbbá ízesíthető és az előállítás helye sem meghatározott. A kereskedelmi forgalomban kapható, illetve magán főzők által előállított vilmoskörte párlatokkal kapcsolatosan minimális tudásunk van. A körte párlatokkal kapcsolatosan mind a nemzetközi, mind a hazai szakirodalomban csak néhány publikált tudományos vizsgálat készült. A párlatok illó komponenseinek minőségi és mennyiségi meghatározása nélkülözhetetlen a párlatom értékmérö tulajdonságainak meghatározásához. A müszeres analitikai vizsgálatok mellett egyre inkább szükség van az objektív érzékszervi módszertanok alkalmazására, és a két eredmény párhuzamba állítására. Ezért munkánkban az alábbi három célkitüzéseket határoztuk meg:

11. Magánfőzésből és kereskedelmi forgalomból származó vilmoskörte párlatok gázkromatográfiás vizsgálata, valamint teljes körü érzékszervi profilanalitikus vizsgálata.

12. Sokdimenziós térredukciós módszerek matematikai hátterének bemutatása, gyakorlati alkalmazási feltételeinek, lehetőségeinek feltárása.

13. Müszeres analitikai és érzékszervi mérések közötti összefüggések meghatározása egy- és többváltozós statisztikai módszerekkel.

\section{Anyag és módszer}

\subsection{A vizsgált párlatok}

Munkánkban 6 magánfózött és 4 kereskedelmi forgalomban kapható vilmoskörte párlat gázkromatográfiás (GC-MS) és érzékszervi profilanalitikus vizsgálatát végeztük el.

\subsection{Gázkromatográfiás vizsgálatok}

A gázkromatográfiás vizsgálatokat a Wessling Hungary Kft, gázkromatográfia és tömegspektrometria (GC-MS) kapcsolt analitikai méréstechnikával. A módszer fejlesztését Berente Bálint végezte. A mintamennyiség $1 \mu$ l pálinka (1:100 split) volt. $\mathrm{Az}$ injektor üveggyapottal töltött split/splitless béléscső, $240^{\circ} \mathrm{C}$-on. Vivőgázként 
héliumot használtunk $1 \mathrm{ml} / \mathrm{min}$, állandó térfogatáram mellett. Az elválasztást ZBWax $30 \mathrm{~m} \times 0,25 \mathrm{~mm} \times 0,25 \mu \mathrm{m}$ gázkromatográfiás oszlopon végeztük, az alábbi hömérsékletprogram alapján: $40^{\circ} \mathrm{C}(2,5 \mathrm{~min}), 8^{\circ} \mathrm{C} / \mathrm{min} 170^{\circ} \mathrm{C}$-ig, $35^{\circ} \mathrm{C} / \mathrm{min} 240^{\circ} \mathrm{C}$ ig $(3,25 \mathrm{~min})$. A Transzfer line hömérsékletprogramja pedig: $170^{\circ} \mathrm{C}(18,5 \mathrm{~min})$, $35^{\circ} \mathrm{C} / \mathrm{min} \quad 240^{\circ} \mathrm{C}$-ig $(3,5 \mathrm{~min})$ volt. A tömegspektrométer ionforrásának hömérséklete $230^{\circ} \mathrm{C}$, míg a kvadrupol analizátor hőmérséklete $150^{\circ} \mathrm{C}$ volt. A detektálást szelektív ionkövetés (selective ion monitoring, SIM) végeztük. Az alábbi vizsgált illókomponensek mennyiségét határoztuk meg minden vizsgálati mintában (mg/l): acetaldehid, etil-acetát, acetál, metanol, sec-butanol, 1-propanol, i-butanol, 1-butanol, 2-metil-1-butanol, 3-metil-1-butanol, metil-butanolok, aceton, metilacetát, etil-propionát, propil-acetát, etil-butirát, 2-metil butil acetát, 3-metil butil acetát, metil butil acetátok, limonén, etil hexanoát, hexil acetát, etil laktát, 1-hexanol, etil oktanoát, furfural benzaldehid, linalool etil dekanoát, etil benzoát, etil-karbamát, etil dodekanoát, allil-alkohol, 2-feniletanol, metil-2-transz-4-cisz-dekadienoát, etil2-transz-4-cisz-dekadienoát.

\subsection{Teljes körủ érzékszervi profilanalitikus vizsgálatok}

Az érzékszervi profilanalitikus vizsgálatok megtervezését, tesztelését és értékelését a vonatkozó nemzetközi szabványnak megfelelően végeztük (ISO 13299:2016). A szórások csökkentése érdekében az érzékszervi vizsgálatokhoz referencia mintát alkalmaztunk. A vizsgálati mintákat véletlen számhármasokkal kódoltuk (növekvő sorrendben): 106, 284, 330, 341, 367, 410, 550, 707, 821, 950. Két vizsgálati blokkot terveztünk a kísérletünkhöz (5+referencia, 4+referencia minta). A szakértői bírálók (ISO 8586:2012) a termékeket két végén leíró kifejezéssel ellátott 0-100-ig terjedő vonalskálán értékelték az alábbi érzékszervi tulajdonságok alapján: globális illat, körte illat, édes illat, gyümölcsillat érett jellege, viaszos illat, globális íz, körte íz, édes íz, savanyú íz, keserü íz, gyümölcs íz érettségének jellege, viaszos íz, íztartósság, szájérzet intenzitások. A vizsgálatokat a Szent István Egyetem Érzékszervi Laboratóriumában (ISO 8589:2007) szakértői bírálócsoport segítségével végeztük. Az érzékszervi bírálói teljesítmény megfelelőségének szoftveres értékelése után (PanelCheck, ISO 11132:2012) a vizsgálati eredmények kiértékelése több lépcsőben történik. Az egyváltozós elemzéseket érzékszervi tulajdonságonként értékeljük (ANOVA). Ahol szignifikáns $(\alpha=0,05)$ különbség adódik, ott Tukey-HSD post hoc tesztet alkalmazunk.

\subsection{Sokdimenziós térredukciós statisztikai módszerek}

Az analitikai és érzékszervi eredményeket külön-külön és együttesen is a fökomponens elemzés (PCA) és többszörös faktorelemzés (MFA) sokdimenziós térredukciós módszerekkel értékeltük. Az MFA input mátrixa két blokkból (GC-MS, érzékszervi) tevődik össze, sorokban a vizsgálati minták, oszlopokban a mért jellemzők állnak, az adatok különböző skálán mért jellege miatt (n-1) standardizálást választottunk (Podani, 2000; Abdi, 2003; Escofier-Pagès, 1990). Az elemzéseket az XL-Stat szoftverrel (Addinsoft, 28 West $27^{\text {th }}$ Street, Suite 503, New York, NY 10001, USA) hajtottuk végre. 


\section{Eredmények és értékelésük}

\subsection{Gázkromatográfiás vizsgálatok eredményei}

A párlatok GC-MS vizsgálatát a Wessling Hungary Kft. végezte, amelyben az illó komponensek mennyiségét határozták meg minden vizsgálati mintában $(\mathrm{mg} / \mathrm{l})$. A metil-2-transz-4-cisz-dekadienoát, etil-2-transz-4-cisz-dekadienoát komponensei jelentős szerepet játszik a vilmoskörte pálinkák aromájának kialakításában, ezért ezeket az eredményeket mutatom be a következőkben (1. táblázat).

\section{1. táblázat: A vizsgált párlatok illó komponenseinek gázkromatográfiás} eredményei (részlet)

\begin{tabular}{ccccccc}
\hline $\begin{array}{c}\text { Minta } \\
\text { azonosítója }\end{array}$ & $\begin{array}{c}\text { etil- } \\
\text { karbamát }\end{array}$ & etil dodekanoát & $\begin{array}{c}\text { allil- } \\
\text { alkohol }\end{array}$ & $\begin{array}{c}\text { 2-fenil- } \\
\text { etanol }\end{array}$ & $\begin{array}{c}\text { metil-2-transz-4- } \\
\text { cisz-dekadienoát }\end{array}$ & $\begin{array}{c}\text { etil-2-transz-4- } \\
\text { cisz-dekadienoát }\end{array}$ \\
\hline 106 & $<0,05$ & $<0,05$ & $<1,0$ & 2,30 & 0,20 & 0,60 \\
\hline 284 & $<0,05$ & 8,40 & $<1,0$ & 6,63 & 7,50 & 28,20 \\
\hline 330 & $<0,05$ & $<0,05$ & $<1,0$ & 1,28 & 11,10 & 28,10 \\
\hline 341 & $<0,05$ & $<0,05$ & $<1,0$ & 3,13 & $<0,1$ & 0,60 \\
\hline 367 & $<0,05$ & $<0,05$ & $<1,0$ & 2,22 & 4,30 & 9,20 \\
\hline 410 & $<0,05$ & 8,80 & $<1,0$ & 4,28 & 4,10 & 21,30 \\
\hline 550 & $<0,05$ & $<0,05$ & $<1,0$ & 12,1 & 1,00 & 1,90 \\
\hline 707 & $<0,05$ & $<0,05$ & $<1,0$ & 0,26 & 4,50 & 11,50 \\
\hline 821 & $<0,05$ & $<0,05$ & $<1,0$ & 4,26 & 14,40 & 31,20 \\
\hline 950 & $<0,05$ & $<0,05$ & $<1,0$ & 3,31 & 2,20 & 5,40 \\
\hline
\end{tabular}

3.2. Érzékszervi profilanalitikus vizsgálatok eredményei

$\mathrm{Az}$ érzékszervi bírálói teljesítmények megfelelőnek adódtak (megkülönböztető képesség, egyetértés, ismétlőképesség) a PanelCheck elemzései alapján. A teljes körü profilanalitikus vizsgálat egyik legfontosabb eredménye a vizsgált termékek érzékszervi profildiagramjai, amely ujjlenyomatszerüen jellemzik a termékeket. A párlatok értékelését egyváltozós elemzésekkel érzékszervi tulajdonságonként is kiértékeltük. Az eredmények azt mutatják, hogy a legnagyobb különbségek a körte illat és körte íz, valamint a keserü és szájérzet jellemzöiben adódtak (1. ábra). 


\section{1. ábra: A vizsgált párlatok profildiagramjai}

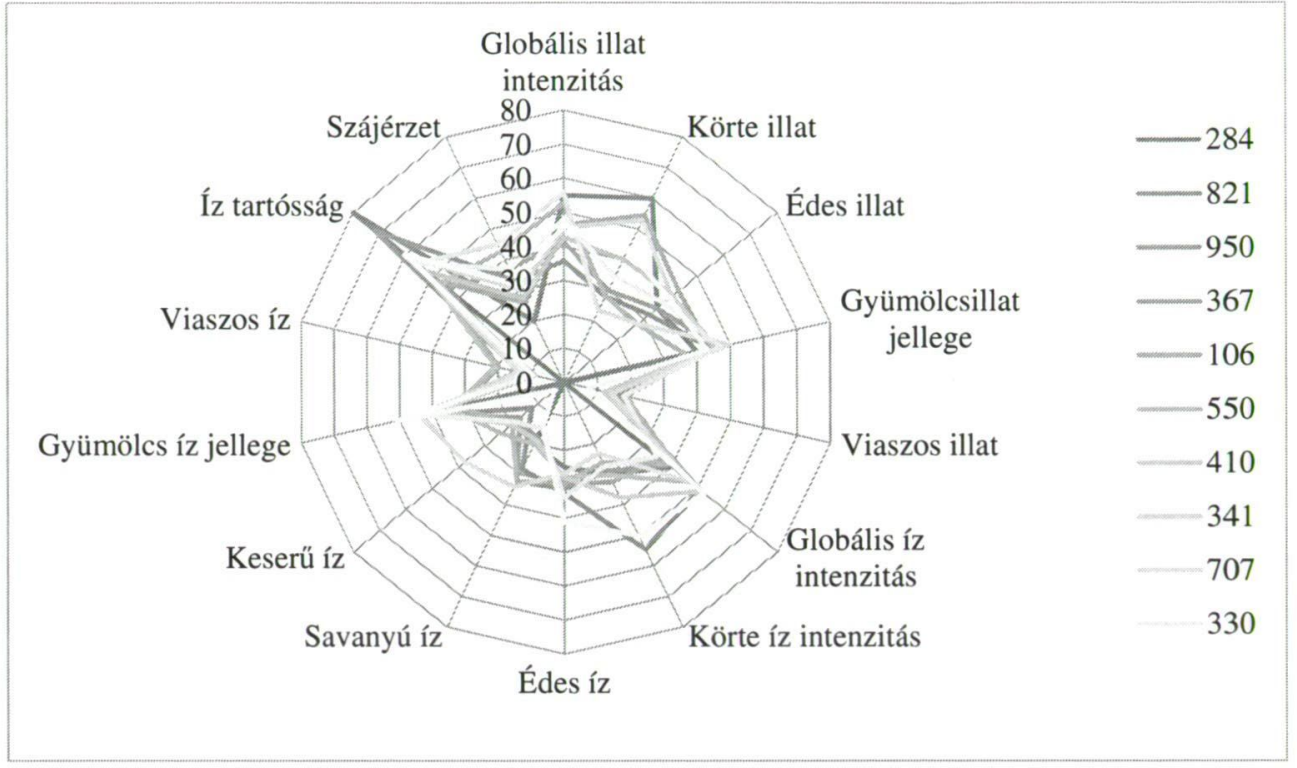

A párlatok összes érzékszervi tulajdonságát figyelembe vevő sokdimenziós értékelését a főkomponens analízis eredményei alapján mutatjuk be (2. táblázat). Számos elgondolás létezik azzal kapcsolatban, hogy hány főkomponenst célszerü figyelembe venni az elemzések során: magyarázott variancia, sajátérték nagysága, hegyomlás ábra stb. Az eredményeket jellemzően az első néhány főkomponens bevonásával mutatják be (Héberger és Rajkó, 2001).

2. táblázat: PCA sajátértékei, varianciái és kumulatív variancia értékei

\begin{tabular}{rrrrrrrrrr}
\hline & F1 & F2 & F3 & F4 & F5 & F6 & F7 & F8 & F9 \\
\hline Sajátérték & 5,196 & 2,995 & 2,084 & 1,395 & 1,167 & 0,637 & 0,332 & 0,106 & 0,088 \\
Variancia (\%) & 37,111 & 21,394 & 14,888 & 9,963 & 8,335 & 4,548 & 2,372 & 0,760 & 0,630 \\
EVariancia (\%) & 37,111 & 58,505 & 73,392 & 83,356 & 91,690 & 96,239 & 98,611 & 99,370 & 100,000 \\
\hline
\end{tabular}

Az újonnan létrejött F1, F2, F3 főkomponensek leginkább korreláló érzékszervi jellemzők érzékszervi tartalmat jelentenek: F1 (keserü íz: 0,835, szájérzet: 0,829; viaszos illat: 0,805, körteillat: -0,792) F2 (körte íz: 0,718, édes íz: 0,752, gyümölcsös íz jellege: 0,674, globális illat: -0,718) F3 (édes illat: 0,771, savanyú íz: -0,514, íz tartósság: -0,538) a legfontosabb magyarázó változói. A párlatok és az érzékszervi jellemzők együttes ábrázolásával (PCA bi-plot) meghatározhatók, a párlatokra leginkább jellemző tulajdonságok. Minél közelebb van az adott fajta egy faktor súlyhoz, annál inkább jellemző rá (2. ábra). 


\section{2. ábra: A párlatok és érzékszervi tulajdonságok bi-plot ábrája}

(F1=37,11\%; F2=21,39\%)

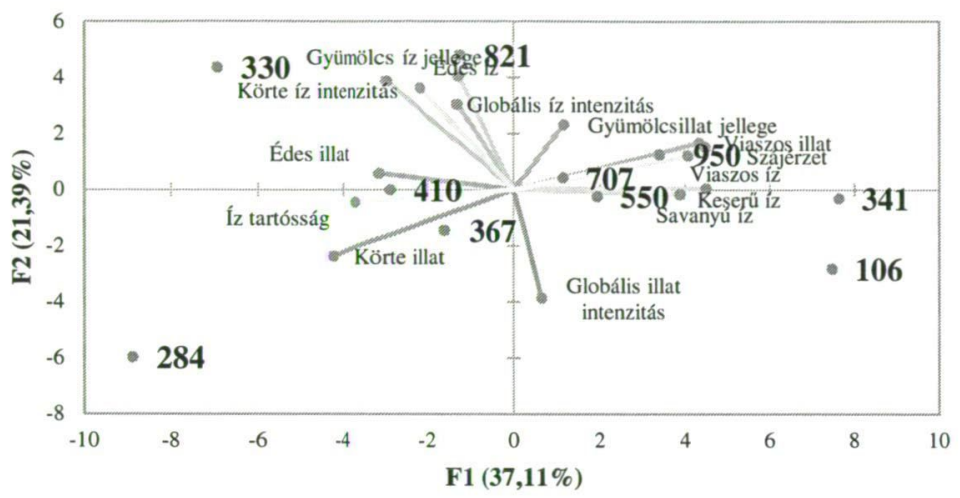

3.3. Gázkromatográfiás és érzékszervi vizsgálatok többváltozós statisztikai módszerekkel történő együttes értékelése

Az MFA eredményeit az első két faktor általi tér alapján mutatjuk be (2. táblázat).

\section{2. táblázat: MFA sajátértékei, varianciái és kumulatív variancia értékei}

\begin{tabular}{rrrrrrrrrr}
\hline & F1 & F2 & F3 & F4 & F5 & F6 & F7 & F8 & F9 \\
\hline Sajátérték & 1,905 & 1,262 & 0,861 & 0,660 & 0,611 & 0,399 & 0,363 & 0,201 & 0,163 \\
Variancia (\%) & 29,655 & 19,640 & 13,395 & 10,267 & 9,506 & 6,218 & 5,657 & 3,126 & 2,536 \\
EVariancia (\%) & 29,655 & 49,295 & 62,689 & 72,956 & 82,462 & 88,680 & 94,338 & 97,464 & 100,000 \\
\hline
\end{tabular}

Az érzékszervi és analitikai változók korrelációs térképe mutatja be a változók közötti kapcsolatot. Körte íz intenzitásához legjobban a metil-2-transz-4-ciszdekadienoát, etil-2-transz-4-cisz-dekadienoát és a propil-acetát, ezeknek a távolsága a körte íz vektortól rendre $0,456,0,645,0,843$. A propil-acetát egygyümölcsös (körte-málna) keserédes íze emlékeztet a körte ízére. Íz tartósság vektor közelében van az etil-2-transz-4-cisz-dekadienoát, etil dekanoát (szőlőre emlékeztető gyümölcsös illat, édes alma íz), acetaldehid (ha nem túl nagy töménységủ, akkor almára emlékeztető illat), etil oktanoát (gyümölcsös virágos illat). Savanyú ízzel korreláló összetevők: etil-acetát (előpárlatosságot jelentő komponens), etil-laktát (vajas illat). Körte illat „közelálló” molekulái az elemzés szerint a 3-metil-1-butanol, 2-metil-1-butanol, etil dodekanoát, 1-butanol, 1-hexanol (távolságok rendre: 0,618, $0,785,0,789,0,841,0,855)$. Etil dodekanoátnak virágos, gyümölcsös illata van. 3metil-1-butanol, illetve a 2-metil-1-butanol igaz, hogy csípősillattal és ízzel rendelkeznek, viszont, ha ezeknek a molekuláknak a mennyisége az észlelhetőségi küszöbszint alatt van, akkor nem jelentenek problémát érzékszervi szempontból (Burdock, 2013).

A párlatok együttes értékelését teszi lehetővé a GC-MS és érzékszervi tulajdonságok MFA ábrája (F1-F2, F1-F3, F2-F3 stb.), amely alapján a közel 
elhelyezkedők hasonlítanak, míg a távol lévők különböznek analitikailag és érzékszervileg egymástól. A következőben néhány jellegzetes mintát, egyenként jellemzünk. 284-es párlatban a körte illat jelen van, viszont már ízében nem hordozza a körte jegyeket, savanyú íz figyelhető meg a termékben. Az etil-2-transz-4-ciszdekadienoát jelenléte jól korrelál a körte ízzel, viszont ebben a párlatban a többi termékhez képest viszonylag magas ez az érték. Valószínüsíthető, hogy amiatt nem érződik a körte íz, mert az etil-2-transz-4-cisz-dekadienoát utópárlatban megjelenő vilmoskörte vezéraroma, s mivel túl sok egyéb utópárlati komponens kerül bele a párlatba, ezért savanyú ízt kapott a párlat, s ez elnyomja a körte ízét. 341-es mintában csak és kizárólag a savanyú és keserü íz dominál erőteljesen, ebben a párlatban legalacsonyabb a vilmoskörte vezéraroma komponensek jelenléte. Többszörös technológia hiba azonosítható, mert nagyon magas az etil-acetát tartalma a párlatnak, ez elválasztási hibára, míg a nagyon alacsony etil-2-transz-4-cisz-dekadienoát és a nem mérhető (hibahatáron belüli) metil-2-transz-4-cisz-dekadienoát pedig cefrézési hibára utal. 821-es termék alacsony körte illat intenzitású, ugyanakkor a körte íz intenzív. Legmagasabb aż etil-2-transz-4-cisz-dekadienoát és a metil-2-transz-4cisz-dekadienoát szintje, de a körte íz eröteljesen dominál. 950-es párlatban a körte illat nincs jelen, keserü íz, savanyú íz, viaszos íz dominál ebben a termékben. Alacsony a vilmoskörte vezéraroma komponensek jelenléte. Alapanyaggal lehetett probléma, illetve a magas etil-acetát tartalom elválasztási problémát jelez.

\section{4. Összefoglalás}

Kutatásunkban a vizsgálatba vont párlatok illó komponenseinek objektív jellemzésére gázkromatográfiás analitikai és objektív érzékszervi profilanalitikus vizsgálatokat végeztünk. Munkánkban alátámasztottuk, hogy a profilanalitikus kiértékelés rendkívül összetett, sokrétü lehetőséget biztosít számunkra a termékek aromafeltárásában, és számos információval szolgál a vizsgálatot végző kutatóknak. A sokdimenziós adatredukciós módszerek (PCA, MFA) segítségével komplex összefüggések tárhatók fel: párlatok elkülönítésének jellemzői (fökomponenseket meghatározó magyarázó változók), párlatok legjellemzőbb érzékszervi tulajdonságai (bi-plot), érzékszervi és analitikai változók közötti korreláció, párlatok hibáinak azonosítása. Ezzel a módszerkombinációval a párlatok élelmiszer-biztonsága és minősége komplexen jellemezhetővé válik.

\section{Köszönetnyilvánítás}

Az Emberi Erőforrások Minisztériuma ÚNKP-17-4 kódszámú Új Nemzeti Kiválóság Programjának támogatásával készültt. A kutatás a Bolyai János kutatási ösztöndíj támogatásával készült.

\section{Irodalomjegyzék}

Abdi, H. (2003): Multivariate analysis. In M. Lewis-Beck, A. Bryman, \& T. Futing (Eds): Encyclopedia for research methods for the social sciences. Thousand Oaks, Sage.

Burdock, G. A. (2013): Fenaroli's handbook of Flavor Ingredients. CRC Press, six edition edition. 
Escofier, B. and Pagès, J. (1990): Multiple factor analysis. Computational Statistics \& Data Analysis, 18: $121-140$.

Héberger, K. Rajkó, R. (2001): Faktoranalízis, fökomponens-elemzés és változataik. In: Horvai Gy. (szerk.): Sokváltozós adatelemzés (kemometria), 71-106.

ISO 11132:2012 Sensory analysis - Methodology - Guidelines for monitoring the performance of $a$ quantitative sensory panel.

ISO 13299:2016 Sensory analysis - Methodology - General guidance for establishing a sensory profile.

ISO 8586:2012 Sensory analysis - General guidelines for the selection, training and monitoring of selected assessors and expert sensory assessors.

ISO 8589:2007 Sensory analysis - General guidance for the design of test rooms.

Podani, J. (2000): Introduction to the Exploration of Multivariate Biological Data. Leiden Backhuys Publishing. 